\title{
EFFECT OF RHEOLOGY OF BLOOD AND HAEMOSTASIS OF THE COWS ON THE VIABILITY OF THE OFFSPRING AND REPRODUCTION
}

\author{
Maria Kambur \\ Doctor of Veterinary Sciences, Professor \\ Sumy National Agrarian University, (Sumy, Ukraine) \\ ORCID: 0000-0002-4864-5292 \\ mariia.kambur@snau.edu.ua
}

\author{
Andriy Zamaziy \\ Doctor of Veterinary Sciences, Professor \\ Poltava State Agrarian Academy, (Poltava, Ukraine) \\ ORCID: 0000-0003-3138-0424 \\ ganavar@ukr.net \\ Oleksandr Nechiporenko \\ Doctor of Veterinary Sciences \\ Sumy National Agrarian University (Sumy, Ukraine) \\ ORCID: 0000-0002-9030-9719 \\ oleksandr.nechyporenko@snau.edu.ua \\ Oleksandr Kalashnyk \\ $\mathrm{PhD}$ in Veterinary Sciences \\ Sumy National Agrarian University, (Sumy, Ukraine) \\ ORCID: 0000-0003-2354-3473 \\ oleksandr.kalashnyk@snau.edu.ua \\ Denis Matveychuk \\ Sumy National Agrarian University, (Sumy, Ukraine) \\ ORCID: 0000-0003-4450-0851 \\ Maksim Kalashnyk \\ Sumy National Agrarian University, (Sumy, Ukraine) \\ ORCID: 0000-0001-5637-2899 \\ oleksandr.kalashnyk@snau.edu.ua
}

The Results of the studies indicate that in $45.44 \%$ of cows-the initial duration of the third period of genera was more than 9 hours, and in cows of the second - third lactation only in $27.28 \%$ of animals. Morphometry indicators of a body mass of newborns calves and placenta show the conditions of growth and development of fetal, which are connected with functional activity of the fetoplacental complex and on average, the body weight of the calves of the first subgroups (animals derived from cows with the duration of the third period of genera up to six hours) proved by $20.80 \%-21.20 \%$ more than the calves of the fourth subgroups. Below the mass proved and placenta of calves, fourth subgroups (in 1.25 by Times -1.18 by Times, $(P<0.05)$, compared to this indicator of the first subgroups of calves. Increased activity of the factors of hemostasis and rheology of blood is set in animals in which the duration of time of the third period of genera was up to 12 and more hours. Under these conditions, the viscosity of animal blood in 1.39-1.40 by Times, $(P<0.05)$ and $1.30-1.40$ by times $(P<0.05)$, the content of Fibrinogen in $2,47-2,04$ by Times $<0.01)$. The given data indirectly indicate the increase of blood viscosity, reduction of its blood flow, especially in the capillary system vessels. In our opinion, this is the cause of the birth of animals with low viability as evidenced by the coefficients of the catabolism factor, oxygenic homeostasis, samples of Mack Klur Aldrich, "immature" surfactant system. Recovery of the reproductive function of cows after calving and duration service period in animals of the first subgroups was in $1.17-1.14$ by times shorter than in cows of the fourth subgroups

Keywords: homeostasis, rheology, hemostasis, balance, vitality

DOl: https://doi.org/10.32845/bsnau.vet.2021.1.1

Introduction. In the intensification of field of livestock, the decisive role of activation of the animal reproduction functions. In order to solve this problem, you are looking for new methods of prevention of obstetric and gynecological diseases of cows, getting of viable offspring with accounting for the complex analysis of causes for violation of reproductive function of animals (Ivashkiv R. M., 2009; Yabnskyi V. A., 2000). A number of researchers, believe (Kryshtoforova B. V.,2007, V. A. Yabloskyi, S. P. Khomych and etc., 2006), in the system of hematopoiesis

and hemostasis (Goryainova I.A., Medvedev I.N., 2005). It is important to provide the essential in hemostasis with thrombosis, which are the first to connect to this process and manifest their extremely important function - adhesion-aggregetic (V.I. Maximov, I.N. Medvedev, 2008; Walker I., 2000).

Physiological changes in the system of hemostasis during pregnancy females - is the reaction of adapting the mother's body to compensatory expenses during fetal excretion and to possible blood loss during genera (Lisovenko V. M., 2014; Zamaziy A. A., Lisovenko V. M., 2014). The factors of hemostasis 
participate in the preservation of liquid with a blood regulation of the trans-cap-ion exchange, resistance to vascular walls, influence the intensity of reparative processes (Zamaziy A. A., Kambur M. D., Lisovenko V. M., 2014). A large number of studies in humane medicine are devoted to studying Issues related to features of hemostasis during pregnancy females (Anastasyeva V.G., 2006; Mazurkevych A. Y., Karpovskyy v. I., Kambur M. D., Zamyziy A. A. etc., 2008). It is proved that (Tsinko T.F, 2007; Yurchenko L.N., Chereshev V.A., Gusev E.Y. etc., 2004) In the structure of reasons of violation of current in cows, development of tribal and post-tribal complications the placenta insufficiency plays a significant role. It is accompanied by vascular spasm with impaired perfusion of vital organs, which is developed in connection with the inconsistency of possibilities of adaptive systems of the maternal organism to respond to the needs of developing fetus. This Mismatch is realized due to changes in the system of hemostasis of the ionic organism and different stupas of perfusion-diffusion insufficiency of the placenta. Result and researches of a number of authors (Opal S.M, Esmon C.T., 2003; Hoffman M, Monroe DM. Coagulation, 2007). The above-mentioned question states that the violation of blood rheology, hemostasis system during pregnancy in cows is accompanied by impaired functional condition of the Feto-placental complex, character the flow of genera and the post-birth period. And the our authors indicate that in the conditions of increasing the capacity of blood supply increases the risk of the blood - embolic complications in the double during pregnancy and 5.5 times after the Paulogs (Markin L. B., Palyga I. E., 2004). They proved that the level of factor I (Fibrinogen) is increasing, which causes an increase in self - damage products of its degradation and factors VII-X. A Number of authors believe that (Prysyazhniuk V. P., 2009; Kayumova L.H., 2009) in the blood clotting system, changes in the growth and development of the fetus occur. Most of the authors indicate a higher blood clotting potential, especially in the last months of being. There is a slight increase in platelet adhesivity, decreased blood Anticoagulation potential, inhibition of fibrinolysis, however, according to other authors of the intravascular combustion of the blood does not occur. These changes contribute to Hemostasis, preventing blood loss in the mouth and the early postoperative period. Researchers believe that when examining issues related to After generic complications in cows it is impossible to take into account Indicators of hemostasis system (Chaikina M., 2008).

They believe that most postoperative complications in cows occur on the basis of weak contractions of the muscular structures of the uterus and depend on the intensity of thrombosis in the vessels of the placental system. Therefore, changes that occur in the system of hemostasis cannot be taken into account when predicting currents or other post-tribal pathology in females (Vink J.Y., 2006; V. A. Yabloskyi, S. P. Khomych and etc., 2006,). Low fibrinolytic activity, reduced blood burn time, low prothromb in time, and time recalcification of the blood plasma in high-performance cows suggest activation of coagulation and fibrhinolytic systems in females, which are borne by the fruit.A number of researchers argue that during the growth and development of fetus in the mother, in the conditions of the physiological norms, conditions are formed for the wide spread internal coagulation of blood. This condition is accompanied by the increase in the general activity of the a huating potential, which is presented by the total activities of the factors of blood coagulation, the increase of platelet functional activity at the current. Also, there is a decrease in fibrinolytic activity in the increase of PPH (product of dehydration fibrinogen), Decrease in activity of antithrombin deficiency III. These peculiarities of the changes in the system of Hemostasis are appropriate for the normal formation of the Feto-placental complex (Kambur M. D., Zamaziy A. A., Koleschko A V., Lermontov A. Yu., Butov O. V., 2018). However, when the requirements to the body of pregnant female dominate the possibilities of protective mechanisms, there is a change in the system of Hemostasis, rheology of Blood, which violate the function of the Feto- placental complex, lead to a violation of the conditions of fetal development, flow of genera and after the birth process, influence on life - bearing of the offspring and testifies to extraordinary Actuality of the given problem.

\section{Materials and Research methods.}

In order to conduct the planned researches by us in the conditions of the State scientific-research business of TV and Sumy Institute APV "Sad" were formed 2 groups of animals with 22 cows each. The first group of animals included heifers, and the second group - cows 2-3 lactation, at the end of the 7th month of growth and fetal development. During the calving, we conducted monitoring of the length of the family process in cows of the first and the second group, conducted blood sampling with a subcutaneous abdominal vein. Taken into account the duration of childbirth stages and depending on these indicators, animals were divided on subgroups depending on the duration of the sequential stage of genera. Before the first subgroups the cows were treated with duration of the rotary process up to 6 hours, second - from 6 to 9 hours, third - from 9 to 12 hours and to the fourth - more than 12 hours.

In samples blood determined rheological Propertiesblood clotting rate, viscosity, thrombocyte (method of ovarian), retraction of blood clot, adhesion of platelets (by the method of Blacksmith), fibrin content (by a weight method), fibrinolysis (according to M. A. Kotovschikova, B. I. Kuznitka).

Using the device coagulometer ac 3002 Ortiz in the blood of animals determined the following indicators of platelet hemostasis: prothrombin time, prothrombin index, thrombin time, activated partially THROMBOPLASTIN time (APTT), fibrinogen content, platelet count (PLT), international normalized ratio (INR), hemoglobin (NGV), Hematocrit (NST), WBC count (WBC), RBC Count (RBC), RBC sedimentation rate (ESR).

The viability of calves determined the weight of the body at birth, the mass of placenta and investigated: - Maturity of the surfactant - alveolar system for the "foaming Test" of Climents (1990) and the test we suggested for "single modification" (A.A. Zamaziy, M. D. Kambur, 2009).

Indicator of oxygenation and acid -core homeostasis determined using analyzer blood gas Easy Blood JAS, Medica, (USA). The sampling of blood samples was carried out using a vacuum container for collecting blood in special test tubes with heparin and urgent on ice delivered for research to the laboratory. Over the next 5 days after the birth of calves determined their viability by the coefficient of Katbotalism and a sample of Mckluar Aldracha.

In the performance of experimental researches the international requirements of «The European Convention for the Protection of vertebrate animals used in the experimental and other scientific purposes» (Strasbourg, France, 1986) and the corresponding law of Ukraine « On the protection of animals from brutal treatment» No 3447-IV of 21.02.2006.

The resulting digital material is processed statistically by means of a computer program with the definition of arithmetic mean $(m)$, statistical error of Arithmetic mean (m), Probability of difference $(p)$ between the average arithmetic two variation series 
According to the authenticity Criterion ( $\mathrm{t}$ ) and according to the Styudent tables. The difference between the two values considered probable in the $P<0.05 ; P<0.01 ; P<0,001$.

Results of the study and their discussions.

The results of the studies testify (table 1), that the length of the family process in cows-the firstborn and the animals of the second-third lactation is significantly different. In cows within the groups. There are also differences in the current of the family process. It was determined that the duration of the first stage of the family process in cows in the first fruits was on average 66,10 \pm 4,20 minutes. In the cows of the first group of the first subgroups this figure was 1.22 times less, and the animals of the second subgroups was at the level of average $(65,00 \pm 4,20 \mathrm{~min})$. Along with this, the duration of the first period of animals of the first group, the third and fourth subgroups was in 1,03-1,16 by Times more $(P<0.05)$ The average duration of the first period of the animal genera of this group.

Duration of periods of the parturition process in cows-firs tborn $(M \pm m)$

Table 1

\begin{tabular}{|c|c|c|c|c|c|}
\hline \multirow{2}{*}{ Indicators } & \multicolumn{5}{|c|}{ I Group } \\
\cline { 2 - 6 } & $\begin{array}{c}\text { to } 6 \text { hours } \\
(\mathrm{n}=6)\end{array}$ & $\begin{array}{c}\text { to } 9 \text { hours } \\
(\mathrm{n}=6)\end{array}$ & $\begin{array}{c}\text { to } 12 \text { hours } \\
(\mathrm{n}=5)\end{array}$ & $\begin{array}{c}\text { more than } 12 \\
\text { hours }(\mathrm{n}=5)\end{array}$ & The average \\
\hline $\begin{array}{c}\text { Duration of the first } \\
\text { period of parturition, min. }\end{array}$ & $54,00 \pm 2,00$ & $65,00 \pm 4,20$ & $68,40 \pm 7,8$ & $77,00 \pm 3,50$ & $66,10 \pm 3,75$ \\
\hline $\begin{array}{c}\text { Duration of the second } \\
\text { period of parturition, min. }\end{array}$ & $58,20 \pm 5,10$ & $66,30 \pm 4,20$ & $74,70 \pm 5,40$ & $79,00 \pm 4,00$ & $69,55 \pm 4,50$ \\
\hline $\begin{array}{c}\text { Duration of the t period of } \\
\text { parturition, min. }\end{array}$ & $352,0 \pm 10,0$ & $560,00 \pm 8,0$ & $620,00 \pm 10$ & $704,00 \pm 8,2$ & $559,0 \pm 9,0$ \\
\hline $\begin{array}{c}\text { Duration of the third } \\
\text { period of parturition, min. }\end{array}$ & $\begin{array}{c}446,20 \pm 5,66 \\
\text { 7,74 }\end{array}$ & $\begin{array}{c}691,30 \pm 10,47 \\
11,52\end{array}$ & $\begin{array}{c}763,10 \pm 7,73 \\
12,72\end{array}$ & $\begin{array}{c}860,00 \pm 11,23 \\
14,33\end{array}$ & $\begin{array}{c}690,15 \pm 10,00 \\
11,50\end{array}$ \\
\hline $\begin{array}{c}\% \text { of the total number of } \\
\text { animals }\end{array}$ & 27,30 & 27,30 & 22,72 & 22,72 & 25,01 \\
\hline
\end{tabular}

Note: $p<0,05 ; p<0,01 ; p<0,001$, in a compare with the cows of the sub-groups.

In cows 2-3 lactation (table. 2) the average duration of the first period of the Rotary process was only 1.05 by times shorter than the animals of the first group. Within the second group, in cows of the first subgroups, the duration of the first period of genera proved in 1.37 by times is shorter than the average animal of this group. In cows of the second and third subgroups, the second group, the first period of genera corresponded to from $68,00 \pm$ 5,00 to $64,20 \pm 5,20 \mathrm{~min}$.

It should be noted that the duration of the second period of genera in the first group of cows was on average 69,55 $\pm 4,50$ $\mathrm{min}$, which practically corresponds to the average lower than of second-group cows $(68,80 \pm 3,95 \mathrm{~min})$. The most significant differences we have found in the animals of each group, but in the heifers of subgroups. In cows-firstborn, the first group, the first subgroups the second period of families lasted at 1.14, in 1,28, in 1.36 by times $(P<0.05)$ less than the animals of the second, third and fourth subgroups. Such a picture, concerning the duration of the second period of our genera is set in the animals of the second group. In these animals the first subgroups, the second period of genera lasted in 1.521 .481 .09 the second, third and fourth subgroups cows $(p<0.01)$. The third period of genera in first group cows lasted, on average $8,42 \pm 0,36$ hours., and the second group's cows only $7,81 \pm 0,42 \mathrm{H}$ (1.08 by Times faster). In cows of the second group, the first subgroups, the duration of the third period of genera was at 1.07 by times, in cows of the second subgroups in 1.03 and the third subgroups in 1.14 by times in shorter than in the animals of the corresponding subgroups of the first group. The body weight of calves received from the second - third cows calving was $22.6-22.4 \%$ higher than that of calves received from first calving cows. On average, the body weight of the calves the first subgroups proved by $20.80 \%-21.20 \%$ more than the calves in the fourth subgroups.

Table 2

\section{Duration of periods of the rotary process in cows of the second-third lactation (MIm)}

\begin{tabular}{|l|c|c|c|c|c|}
\hline \multirow{2}{*}{ Indicators } & \multicolumn{5}{|c|}{ II Group } \\
\cline { 2 - 6 } & $\begin{array}{c}\text { to } 6 \mathrm{~h} \\
(\mathrm{n}=8)\end{array}$ & $\begin{array}{c}\text { to } 9 \mathrm{~h} \\
(\mathrm{n}=8)\end{array}$ & $\begin{array}{c}\text { to } 12 \mathrm{~h} \\
(\mathrm{n}=3)\end{array}$ & $\begin{array}{c}\text { More than } 12 \\
\text { hours }(\mathrm{n}=3)\end{array}$ & The average \\
\hline Duration of the first period of parturition, min. & $46,00 \pm 4,00$ & $68,00 \pm 5,00$ & $64,20 \pm 5,20$ & $73,00 \pm 4,00$ & $62,8 \pm 4,50$ \\
\hline $\begin{array}{l}\text { Duration of the second period of parturition, } \\
\text { min. }\end{array}$ & $54,00 \pm 3,00$ & $59,20 \pm 4,10$ & $79,80 \pm 5,20$ & $82,20 \pm 3,40$ & $68,8 \pm 3,40$ \\
\hline Duration of the t period of parturition, min. & $324,00 \pm 6,00$ & $540,00 \pm 5,00$ & $604,20 \pm 8,10$ & $696,00 \pm 8,00$ & $541,05 \pm 6,30$ \\
\hline Duration of the third period of parturition, min. & $\begin{array}{c}424,00 \pm 14,33 \\
7,07\end{array}$ & $\begin{array}{c}661,20 \pm 14,70 \\
11,02\end{array}$ & $\begin{array}{c}748,20 \pm 12,40 \\
12,47\end{array}$ & $\begin{array}{c}851,20 \pm 9,40 \\
14,19\end{array}$ & $\begin{array}{c}671,15 \pm 10,02 \\
11,19\end{array}$ \\
\hline$\%$ of the total number of animals & 36,36 & 36,36 & 13,64 & 13,64 & 25,00 \\
\hline $\mathrm{n}$ & 8 & 8 & 3 & 3 & 22,0 \\
\hline
\end{tabular}

Note: $p<0,05 ; p<0,01 ; p<0,001$, in the compare with the cows of the subgroups.

The mass below proved and placenta of calves, fourth subgroups (in 1.25 by times -1.18 by Times, $(P<0.05)$, compared with this indicator of the calves Pershix Rup. Appearance of placenta of newborn calves is also different. In terms of the duration of the third period of genera up to six hours, the vascular system is clearly defined in placenta (Fig 1).
At the same time, at extension of the third period of genera more than 12 hours the placenta has no clear picture of blood vessels, there are areas of inflammation, stagnation of blood (Fig. 2). 

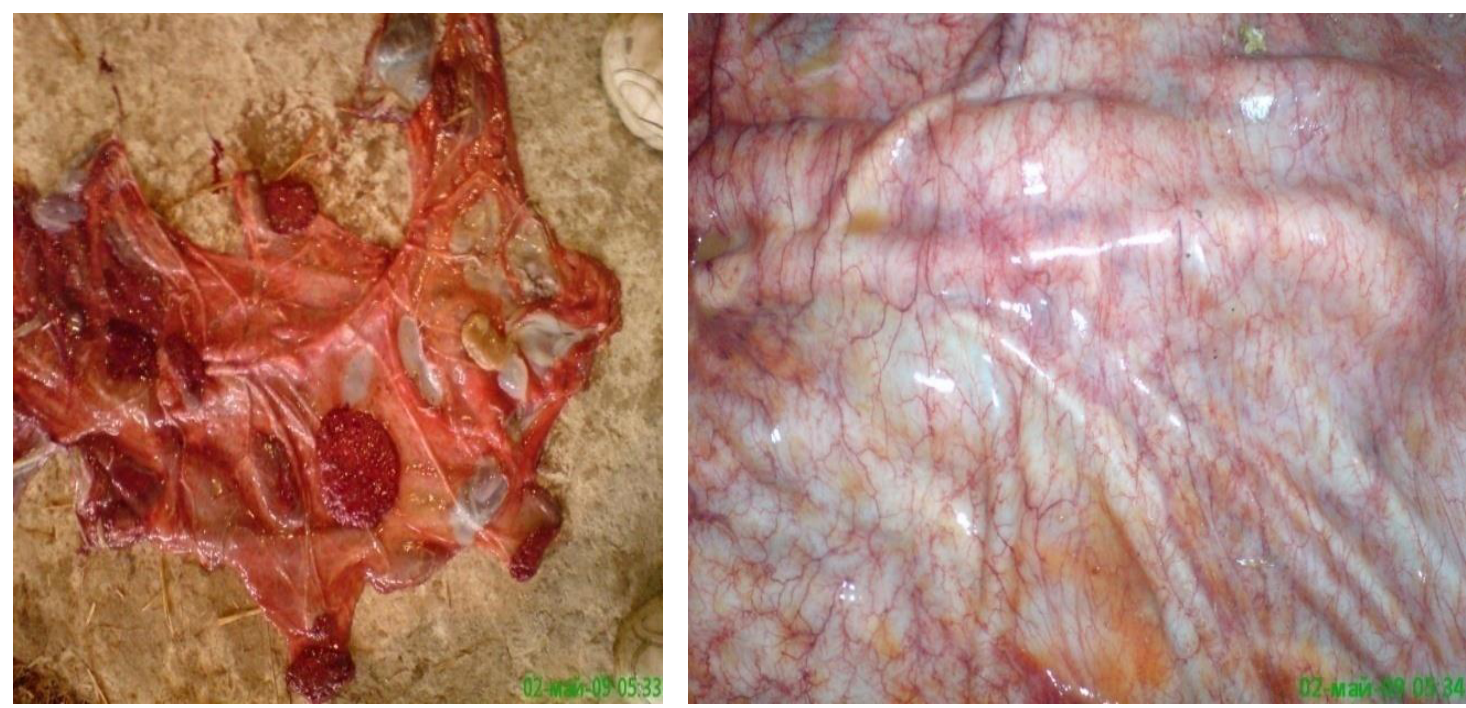

Fig 1. Appearance of placenta of newborn calves, the first subgroups.

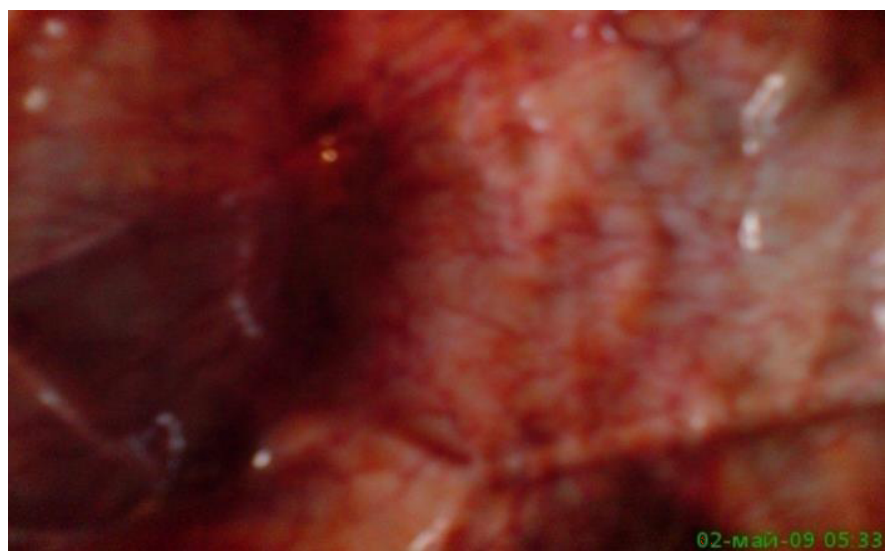

Fig. 2. Appearance of placenta of newborn calves received from cows with duration of the third period of genera more than 12 hours.

It is necessary to specify (table. 3 ) that in cows of both groups the blood viscosity increased according to the length of the family process. In cows that have 2-4 subgroups, the first group, blood viscosity proved probably more than the cows of the first subgroups (in 1.09 , in 1.39 and 1.40 by Times, $(p<0.05)$.In The research animals of the second group, second, third, and fourth subgroups, blood viscosity, also was the larger given indicator of the cows of the first subgroups in $1.07,1.30$ and 1.40 by times $(P<0.05)$. Apart from this, it should not be noted that in the research animals of the first group, all sub-groups of blood viscosity were respectively in 1.03 , at 1.05 , in 1.10 and in 1.04 more than in the research cows of the second group. In our opinion, this indicator demonstrates the receipt of blood to the fetus from the maternal body of cows - the firstborn is slower than in cows of the second-third lactation.

Properties of blood cows depending on the duration of the sequential stage of parturition $(\mathrm{M} \pm \mathrm{m})$

\begin{tabular}{|l|l|l|l|l|l|l|}
\hline \multirow{2}{*}{$\begin{array}{c}\text { Groups of animals/ } \\
n\end{array}$} & $\begin{array}{c}\text { Blood viscosity, } \\
\text { gr. }\end{array}$ & $\begin{array}{c}\text { Blood coagulation } \\
\text { rate, min. }\end{array}$ & Fibrinolisis, min. & $\begin{array}{c}\text { Thrombophase, } \\
\text { st. }\end{array}$ & $\begin{array}{c}\text { Retraction Blood } \\
\text { clot, } \%\end{array}$ & $\begin{array}{c}\text { Adhesion of platelets, } \\
\%\end{array}$ \\
\hline \multicolumn{7}{|c|}{ First group cows } \\
\hline I subgroup, $n=6$ & $5,02 \pm 0,16$ & $402,00 \pm 5,00$ & $5,02 \pm 0,76$ & $4,14 \pm 0,12$ & $48,30 \pm 1,20$ & $39,24 \pm 1,32$ \\
\hline II subgroup, $n=6$ & $5,48 \pm 0,24$ & $386,00 \pm 4,00$ & $5,90 \pm 0,54$ & $4,86 \pm 0,10$ & $48,40 \pm 1,50$ & $40,22 \pm 1,54$ \\
\hline III subgroup, $n=5$ & $6,92 \pm 0,26$ & $354,00 \pm 5,00$ & $6,30 \pm 0,40$ & $5,60 \pm 0,05$ & $51,20 \pm 1,44$ & $40,68 \pm 1,46$ \\
\hline IV subgroup, $n=5$ & $7,02 \pm 0,18$ & $338,00 \pm 6,00$ & $6,60 \pm 0,30$ & $5,50 \pm 0,10$ & $52,50 \pm 13,00$ & $41,20 \pm 1,38$ \\
\hline \multicolumn{7}{|c|}{ Second group cows } \\
\hline I subgroup, $n=8$ & $4,88 \pm 0,14$ & $414,00 \pm 5,00$ & $4,80 \pm 0,50$ & $4,00 \pm 0,15$ & $48,20 \pm 2,02$ & $38,40 \pm 2,02$ \\
\hline II subgroup, $n=8$ & $5,24 \pm 0,26$ & $394,00 \pm 4,00$ & $5,70 \pm 0,62$ & $4,00 \pm 0,08$ & $49,10 \pm 1,96$ & $38,80 \pm 1,96$ \\
\hline IIIsubgroup, $n=3$ & $6,32 \pm 0,22$ & $376,00 \pm 4,00$ & $6,20 \pm 0,48$ & $4,20 \pm 0,10$ & $50,40 \pm 1,34$ & $39,60 \pm 1,20$ \\
\hline IVsubgroup, $n=3$ & $6,78 \pm 0,24$ & $354,00 \pm 6,00$ & $6,50 \pm 0,50$ & $4,50 \pm 0,12$ & $51,20 \pm 1,52$ & $40,20 \pm 1,34$ \\
\hline
\end{tabular}

Note: $p<0,05 ; p<0,01 ; p<0,001$, in the comparison with the cows of the subgroups.

In research animals of the first group, the first subgroup, the speed of blood coagulation had the highest figure. In animals of the second-fourth subgroups, the first group, This process accelerated in 1.04 , in 1.14 and in 1.19 by times $(P<0.05)$, and in the animals corresponding subgroups, the second group in 1.05 , in 1.10 and in 1.17 by times $(P<0.05)$ compared to the animals the first subgroups

Blood viscosity has the same dynamics with fibrinosis. In the cows of the second, third and fourth subgroups, Fibrinolysis took place longer than the first subgroups in the animals in 1.18, 
1.25, in 1.31 and in 1.19, in 1.29, in 1.35 by times $(P<0.05)$. The retractor was much higher than the resuscitation of blood clots and adhesion of platelets in cows in which the third period of genera lasted over 9 hours.

The results of the studies are shown in the table4shows that in the body of cows-firstborn. The activation of the factors of hemostasis is more active during the carrying of the fetus.

The results of the studies are shown in the table4 shows that in the body of cows-firstborn The activation of the factors of hemostasis is more active during the carrying of the fetus.
Thrombin time, is also an important indicator of blood clotting speed: the obtained data show that this indicator is shorter in the cows of the first group at 1.03, at 1.08, in 112 ( $p<0.05)$, in 1.05 by times compared to the animals of the relevant subgroups, the second group.

Significant influence on blood viscosity, and accordingly on its movement on vessels has the content of fibrinogen. Increasing the length of the rotary process in cows is accompanied by an increase in blood fibrinogen. Thus, its blood content in the first subgroups of cows appeared in the $2,47-2,04$ by Times $(p<0.01)$ less than those of the fourth subgroup animals.

Table 4

Results of the cows hemostasis with different duration of the third period of partutition (MIm)

\begin{tabular}{|l|c|c|c|c|}
\hline \multirow{2}{*}{ Indicators } & \multicolumn{3}{|c|}{ Hours } \\
\cline { 2 - 4 } & $\begin{array}{c}\text { to } 6 \mathrm{~h} \\
\text { (I subgroup, }\end{array}$ & $\begin{array}{c}\text { to } 9 \mathrm{~h} \\
\text { (Il subgroup) }\end{array}$ & $\begin{array}{c}\text { to } 12 \mathrm{~h} \\
\text { (III subgroup) }\end{array}$ & $\begin{array}{c}\text { More than } 12 \text { hours } \\
\text { (IVsubgroup) }\end{array}$ \\
\hline \multirow{2}{*}{ Prothrombin time, Sec } & $26,47 \pm 2,24$ & $25,73 \pm 0,63$ & $25,25 \pm 1,66$ & $25,33 \pm 0,98$ \\
\hline \multirow{2}{*}{ Prothrombin Index,\% } & $27,20 \pm 1,40$ & $26,10 \pm 0,70$ & $27,90 \pm 2,30$ & $26,96 \pm 0,94$ \\
\hline Internationally & $42,53 \pm 4,78$ & $42,03 \pm 3,96$ & $33,67 \pm 2,11$ & $33,37 \pm 1,24$ \\
\cline { 2 - 5 } Normalised ratio (INR), \% & $44,40 \pm 2,20$ & $43,08 \pm 2,84$ & $36,96 \pm 1,24$ & $35,42 \pm 2,02$ \\
\hline \multirow{2}{*}{ Thrombin time, Sec } & $1,95 \pm 0,17$ & $1,96 \pm 0,04$ & $2,24 \pm 0,13$ & $1,80 \pm 0,09$ \\
\hline Active partially & $1,98 \pm 0,22$ & $2,02 \pm 0,14$ & $2,28 \pm 0,16$ & $2,20 \pm 0,10$ \\
\hline Thrombin time, Sec & $38,83 \pm 2,60$ & $38,10 \pm 0,85$ & $36,57 \pm 4,95$ & $35,73 \pm 1,00$ \\
\hline \multirow{2}{*}{ Fibrinogen, gr/l } & $39,94 \pm 2,40$ & $40,96 \pm 0,73$ & $40,82 \pm 3,16$ & $37,46 \pm 2,23$ \\
\cline { 2 - 5 } & $41,10 \pm 3,12$ & $39,47 \pm 1,36$ & $35,93 \pm 4,11$ & $34,80 \pm 1,40$ \\
\cline { 2 - 5 } & $42,40 \pm 2,20$ & $41,04 \pm 1,94$ & $36,42 \pm 2,12$ & $35,94 \pm 2,12$ \\
\cline { 2 - 5 } & $2,32 \pm 0,37$ & $2,44 \pm 0,19$ & $4,37 \pm 0,10$ & $5,74 \pm 0,41$ \\
\hline
\end{tabular}

Note: $p<0,05 ; p<0,01 ; p<0,001$, in comparison with the cows of the first subgroups: numerator-cow-the firstborn; denominator - second-third lactation cows

These data indirectly indicate the increase of blood viscosity, reduction of its blood flow, especially in the capillary system vessels that cause placental insufficiency and adversely affects the growth and development of the fetus, and accordingly Birth of animals with low viability.

The data is obtained regarding erythrocytic and leukocyte in cows with different childbirth duration (table 5) allow to assert activity of these processes in the organism of animals in the process of fetal bearing. However, the number of leukocytes and red blood cells in the blood of the first and second group cows is significantly different, which in our opinion indicates different levels of protective mechanisms of the body.

Table 5

Erythrocytic and leukocyticindicators for cows with different duration of general (MIm)

\begin{tabular}{|l|c|c|c|c|}
\hline \multirow{2}{*}{ Indicators } & \multicolumn{4}{|c|}{ Hours } \\
\cline { 2 - 5 } & $\begin{array}{c}\text { Up to } 6 \text { hours } \\
\text { (first subgroup) }\end{array}$ & $\begin{array}{c}\text { Up to 9 hours } \\
\text { (second subgroup) }\end{array}$ & $\begin{array}{c}\text { Up to 12 hours } \\
\text { (third subgroup) }\end{array}$ & $\begin{array}{c}\text { More than } 12 \text { hours } \\
\text { (fourth subgroup) }\end{array}$ \\
\hline \multirow{2}{*}{ Leukocytes, g/L } & $14,60 \pm 0,35$ & $18,50 \pm 1,98$ & $16,80 \pm 2,10$ & $17,33 \pm 2,10$ \\
\cline { 2 - 5 } & $12,20 \pm 0,40$ & $17,30 \pm 2,20$ & $15,20 \pm 2,00$ & $15,40 \pm 1,90$ \\
\hline \multirow{2}{*}{$\begin{array}{l}\text { Erythrocyte sedimentation } \\
\text { rate, } \mathrm{mm} / \mathrm{h}\end{array}$} & $2,02 \pm 0,14$ & $2,04 \pm 0,12$ & $2,00 \pm 0,10$ & $2,00 \pm 0,10$ \\
\cline { 2 - 5 } & $2,42 \pm 0,22$ & $2,20 \pm 0,10$ & $2,18 \pm 0,12$ & $2,02 \pm 0,14$ \\
\cline { 2 - 5 } & $6,85 \pm 0,26$ & $6,53 \pm 0,29$ & $6,54 \pm 0,32$ & $6,45 \pm 0,51$ \\
\hline \multirow{2}{*}{ RBCs, $\mathrm{t} / \mathrm{L}$} & $6,96 \pm 0,34$ & $6,88 \pm 0,18$ & $6,92 \pm 0,22$ & $7,02 \pm 0,24$ \\
\cline { 2 - 5 } & $111,33 \pm 1,33$ & $110,33 \pm 4,58$ & $111,00 \pm 1,65$ & $106,33 \pm 0,88$ \\
\hline \multirow{2}{*}{ Hematont hb, G/L } & $118,20 \pm 2,00$ & $116,30 \pm 3,20$ & $115,40 \pm 2,20$ & $110,00 \pm 2,00$ \\
\cline { 2 - 5 } & $27,33 \pm 2,03$ & $26,00 \pm 3,44$ & $25,00 \pm 1,47$ & $25,00 \pm 1,53$ \\
\hline
\end{tabular}

Note: $p<0,05 ; p<0,01 ; p<0,001$ in comparison with the animals of the first subgroups; Numerator-and group, cow-firstborn; denominator- Il group, cows of the second-third lactation.

It should be noted that regardless of the group in the cows with a continuation of the duration of the family process, the number of blood cells is reduced, which we associate with exhaustion of the processes of leukocyte and erythrocytic. The duration of the genitive process of the cow influenced the oxygen homeostasis of newborn calves (table 6).

Elongation of the family process for more than 9 hours in the cows of the third and fourth subgroups has a negative impact on the parameters of the oxygenic homeostasis of newborns. In newborn animals the $\mathrm{pH}$ of data was found at 2,30-2,85\% and $1.04-2,53 \%$ less than the calves of the first subgroups, first and second group. This in our opinion demonstrates the acidotic displacement.
The partial pressure of $\mathrm{CO}_{2}$ in the calf blood received from the cows of the second, third and fourth subgroups, the first group, was in 1.23 , at 1.60 , in 1.59 by times $(P<0.01)$, and in the calves corresponding subgroups, the second group in 1.18, at 1.57 , in 1.56 by Times more $(P<0.01)$ than the calves of the first subgroups.

Such dynamics we have established and according to the index of blood carbon dioxide. In favor of our opinion, that lengthening the family process in cows causes an actangent shift in the body of the fetus, and is manifested in indicators of the oxygenic Newborns ' homeostasis show data on the presence of animal blood. 
Table 6

Oxygenic Homeostasis of newborn calves(M $(\mathrm{m})$

\begin{tabular}{|l|c|c|c|c|c|c|}
\hline \multirow{2}{*}{ Calf groups/ $\mathrm{n}$} & \multicolumn{7}{c|}{ Indicators } \\
\cline { 2 - 8 } & $\mathrm{pH}$ & $\begin{array}{c}\mathrm{PCO}_{2,} \\
\mathrm{mmh}\end{array}$ & $\begin{array}{c}\mathrm{BEB}, \\
\mathrm{mmol} / \mathrm{L}\end{array}$ & $\begin{array}{c}\mathrm{BE} \text { ect, } \\
\mathrm{mmol} / \mathrm{L}\end{array}$ & $\mathrm{TCO}_{2,} \%$ & $\mathrm{HCO}_{3,}$ \\
\hline \multicolumn{7}{|c|}{ First group calves: } \\
\hline I subgroup, $\mathrm{n}=6$ & $7,372 \pm 0,08$ & $45,80 \pm 0,94$ & $1,88 \pm 0,12$ & $2,02 \pm 0,22$ & $27,94 \pm 0,54$ & $27,56 \pm 1,02 \pm$ \\
\hline II subgroup, $\mathrm{n}=6$ & $7,264 \pm 0,06$ & $56,60 \pm 0,80$ & $1,36 \pm 0,16$ & $1,84 \pm 0,18$ & $32,06 \pm 0,96$ & $27,94 \pm 0,96$ \\
\hline III subgroup, $\mathrm{n}=5$ & $7,206 \pm 0,11$ & $73,40 \pm 0,75$ & $1,86 \pm 0,18$ & $0,52 \pm 0,08$ & $32,16 \pm 0,78$ & $28,36 \pm 0,82$ \\
\hline IV subgroup, $\mathrm{n}=5$ & $7,168 \pm 0,16$ & $72,90 \pm 0,60$ & $2,86 \pm 0,08$ & $0,78 \pm 0,12$ & $33,08 \pm 0,94$ & $22,92 \pm 0,78$ \\
\hline \multicolumn{7}{|c|}{ Second group calves: } \\
\hline I subgroup, $\mathrm{n}=8$ & $7,384 \pm 0,08$ & $44,90 \pm 0,40$ & $1,94 \pm 0,12$ & $2,24 \pm 0,26$ & $26,84 \pm 0,76$ & $27,08 \pm 0,76$ \\
\hline II subgroup, $\mathrm{n}=8$ & $7,356 \pm 0,12$ & $52,80 \pm 0,52$ & $1,52 \pm 0,16$ & $2,02 \pm 0,18$ & $31,96 \pm 0,82$ & $27,54 \pm 0,84$ \\
\hline III subgroup, $\mathrm{n}=3$ & $7,308 \pm 0,10$ & $70,40 \pm 0,64$ & $0,96 \pm 0,13$ & $1,06 \pm 0,16$ & $32,08 \pm 0,94$ & $27,96 \pm 0,92$ \\
\hline IV subgroup, $\mathrm{n}=3$ & $7,202 \pm 0,12$ & $71,20 \pm 0,36$ & $1,78 \pm 0,16$ & $0,54 \pm 0,08$ & $32,12 \pm 0,72$ & $29,06 \pm 0,68$ \\
\hline
\end{tabular}

Note: $p<0,05 ; p<0,01 ; p<0,001$, in comparison with calves before the first subgroups.

Thus, the first-to-fourth subgroups calves had a negative designation in the newborns ' 1 st and 3rd group. In calves of corresponding subgroups, the second group Was also 0,96 $\pm 0,13$ and $-1,78 \pm 0,16 \mathrm{mmol} / \mathrm{L}$.

On the negative impact of lengthening of the family process on the viability of the newborn calves (table 7), evidence of "maturity" of the surfactant-alveolar lung system. Lengthening of the family process in cows of third-fourth subgroups, both groups, lowered the "maturity" of the newborn calves lungs and shows a violation of the organism's provision with oxygen.

"Maturity" of the surfactant-alveolar system of newborn calves for "foam test" and "one expiratory test" (\%)

\begin{tabular}{|c|c|c|c|c|c|c|c|c|}
\hline \multirow{4}{*}{ Calf groups } & \multicolumn{4}{|c|}{ "Foam Test" } & \multicolumn{4}{|c|}{ "One exhalation test" } \\
\hline & \multicolumn{2}{|c|}{ Negative } & \multicolumn{2}{|c|}{ Positive } & \multicolumn{2}{|c|}{ Negative } & \multicolumn{2}{|c|}{ Positive } \\
\hline & $n$ & $\%$ & $\mathrm{n}$ & $\%$ & $\mathrm{n}$ & $\%$ & $\mathrm{n}$ & $\%$ \\
\hline & \multicolumn{8}{|c|}{ First group calves } \\
\hline I subgroup, $n=6$ & 4 & 66,67 & 2 & 33,33 & 3 & 50,00 & 3 & 50,00 \\
\hline II subgroup, $n=6$ & 4 & 66,67 & 2 & 33,33 & 3 & 50,00 & 3 & 50,00 \\
\hline III subgroup, $n=5$ & 3 & 60,00 & 2 & 40,00 & 3 & 60,00 & 2 & 40,00 \\
\hline IV subgroup, $n=5$ & 3 & 60,00 & 2 & 40,00 & 1 & 20,00 & 4 & 80,00 \\
\hline \multicolumn{9}{|c|}{ Second group calves } \\
\hline I subgroup, $n=8$ & 7 & 87,50 & 1 & 12,5 & 5 & 62,50 & 3 & 37,50 \\
\hline II subgroup, $n=8$ & 8 & 100,00 & - & 0 & 6 & 75,00 & 2 & 25,00 \\
\hline III subgroup, $n=3$ & 2 & 66,67 & 1 & 33,33 & 2 & 66,67 & 1 & 33,33 \\
\hline IV subgroup, $n=3$ & 2 & 66,67 & 1 & 33,33 & 1 & 33,33 & 2 & 66,67 \\
\hline Total & 3 & 71,77 & 11 & 28,23 & 24 & 52,19 & 20 & 47,82 \\
\hline
\end{tabular}

Note: $p<0,05 ; p<0,01 ; p<0,001$, in comparison with calves of the first subgroups.

Thus, by both tests, the positive characteristic is $40 \%$ of newborn calves, third subgroups, the first group and $50 \%$ of the calves of the third subgroups. Considerably fewer calves with "immature" MF are born in cows 2-3 lactation (animals of the Second research group).

Sample Indicators Mac Klyr Oldrich (table.8) newborn calves of third group - The fourth subgroups show violations of the fetal growth and development process, and consequently the viability of newborn animals.

Calves, that are derived from cows in which the generic process continues higher physiological rate, on the first day of birth (Animals of the third-fourth subgroups) test Mac Klur Oldrichwasserving 1,10-1.15 by times faster than calves received from the cows of the first subgroups, the first group. At calves from the second group's cows, the first subgroups, the fisolution resorption process lasted at 1.03 , in 1.05 and 1.15 by times $(P<$ 0.05 ) longer than the calves of the second-fourth subgroups. At 3 and 4 days of living in calves of the third-fourth sub-group, the MCP Aldrich is less than the calves received from the first subgroups.

Table 8

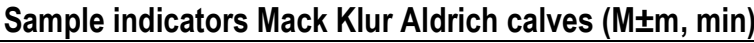

\begin{tabular}{|l|c|c|c|}
\hline \multirow{2}{*}{ Calf groups } & \multicolumn{3}{c|}{ Test Mac Klur Oldrich on } \\
\cline { 2 - 4 } & 1st day & 3d day & 5th Day \\
\hline \multicolumn{3}{|c|}{ First group calves } \\
\hline - I subgroup, $\mathrm{n}=6$ & $57,60 \pm 0,80$ & $58,20 \pm 1,00$ & $58,60 \pm 0,90$ \\
\hline - II subgroup, $\mathrm{n}=6$ & $56,40 \pm 0,90$ & $57,60 \pm 1,20$ & $58,20 \pm 1,00$ \\
\hline - III subgroup, $\mathrm{n}=5$ & $52,20 \pm 1,10$ & $52,40 \pm 0,90$ & $52,80 \pm 1,00$ \\
\hline - IV subgroup, $\mathrm{n}=5$ & $50,30 \pm 0,70$ & 50,50 & $\pm 0,90$ \\
\hline Second group calves & $60,20 \pm 1,02$ & $61,60 \pm 1,10$ & $62,10 \pm 0,90$ \\
\hline - I subgroup, $\mathrm{n}=8$ & $58,40 \pm 1,10$ & $59,30 \pm 0,80$ & $60,00 \pm 1,00$ \\
\hline - II subgroup, $\mathrm{n}=8$ & $57,60 \pm 0,80$ & $58,00 \pm 1,04$ & $57,80 \pm 0,60$ \\
\hline - III subgroup, $\mathrm{n}=3$ & $52,40 \pm 0,80$ & $52,60 \quad \pm 0,90$ & $52,20 \pm 0,80$ \\
\hline - IV subgroup, $\mathrm{n}=3$ & \multicolumn{3}{|c|}{} \\
\hline
\end{tabular}

Note: $P<0.05 ; P<0.01 ; P<0,001$, compared to calves before the first subgroups. 
In our opinion, this is also an indicator of fetal underdevelopment, associated with the conditions of formation of fetoplacental complex and providing the fetus with nutrients and Oxygen. On interrelation of prenatal fetal development and one hundred of new born calves (table 9) indicators of catabolism coefficient are showed.

The calves of the first subgroups present the figure from the first to the fifth day of life decreases in $1,10-1.11$ by Times $(P$ $<0.05)$, What testifies to the anabolism processes in the organism of others. In calves of the third and fourth subgroups, the coefficient of catabolism on the third day is practically identical to the indicator of the first day. That is, in the body of animal data for the third day, the first of the process of catabolism is preserved, and on the fifth day this coefficient It turns out only in 1,05-1.04 by Times less, This indicator of the first day of life of calves.

In our opinion, this is also an indirect indicator of the conditions of growth and development of the fetus, which in the higher degree depends on the efficiency of the functioning of the blood fetus system, matching DNA and nutrients and oxygen. You must specify the following. The duration of the family process of cows was reflected on restoration of the reproduction function of cows after calving (table 10). Thus, the violation of the third period of genera resulted in a delay of the litter of 4 cows of the first group (18.18\%) And in one animal of the second group $(4.35 \%)$. III with endometritis $18.18 \%$ of cows-the firstborn and $9.10 \%$ of the cows of the second-third lactation.

Table 9

The coefficient of catabolism of newborns and neonate period of calves( $M \pm m)$

\begin{tabular}{|l|c|c|c|}
\hline \multirow{2}{*}{ Calf groups } & \multicolumn{3}{c|}{ The coefficient of catabolism } \\
\cline { 2 - 4 } & 1st day & 3d day & 5th Day \\
\hline \multicolumn{3}{|c|}{ First group calves } \\
\hline - I subgroup, $\mathrm{n}=6$ & $0,990 \pm 0,15$ & $0,972 \pm 0,22$ & $0,904 \pm 0,12$ \\
\hline - II subgroup, $\mathrm{n}=6$ & $0,996 \pm 0,18$ & $0,986 \pm 0,18$ & $0,916 \pm 0,18$ \\
\hline - III subgroup, $\mathrm{n}=5$ & $1,020 \pm 0,16$ & $1,010 \pm 0,25$ & $0,090 \pm 0,22$ \\
\hline - IV subgroup, $\mathrm{n}=5$ & $1,030 \pm 0,20$ & $1,010 \pm 0,20$ & $0,986 \pm 0,20$ \\
\hline \multicolumn{3}{|c|}{ Second group calves } \\
\hline - I subgroup, $\mathrm{n}=8$ & $0,980 \pm 0,22$ & $0,970 \pm 0,20$ & $0,980 \pm 0,15$ \\
\hline - II subgroup, $\mathrm{n}=8$ & $0,996 \pm 0,30$ & $0,980 \pm 0,15$ & $0,960 \pm 0,20$ \\
\hline - III subgroup, $\mathrm{n}=3$ & $1,040 \pm 0,20$ & $1,030 \pm 0,20$ & $0,996 \pm 0,18$ \\
\hline - IV subgroup, $\mathrm{n}=3$ & $1,036 \pm 0,18$ & $1,024 \pm 0,10$ & $0,998 \pm 0,24$ \\
\hline
\end{tabular}

Note: $P<0.05 ; P<0.01 ; P<0,001$, compared to calves before the first sub-groups.

The duration of allocation of elements in the research animals of the first group ranged and found itself in cows of the second subgroups in 1.11 , by Times, the third subgroups in 1.28 , the fourth subgroups in 1.32 by times longer than the animals of the first subgroups $(P<0.05)$. The animals of the second group within the subgroup are set as follows: In cows the first subgroups duration The fourth subgroups $(P<0.05)$. At the same time, the comparison of the time of isolation of the elements in cows of the first and second group, within the subgroups, testifies, however that in cows of the first group the process took place in 1.04, in
1.17 , in 1.13 and in 1.10 by Times longer $(P<0.05)$. We set a similar dynamics regarding the yellow body lysis. On average lysis of yellow bodies in the first group's cows took up 24,6 $\pm 2,00$ days, which is 1.11 by times longer than the second group's cows. The above-mentioned processes influenced the time of the first cows insemination. The first group of cows the process took place on average $88,00 \pm 2,00$ day after calving and was on $8,00 \pm$ 1,00 days longer than in cows of the second group. Effective insemination of first-group cows on average, took place in 1.10 by times $(P<0.05)$ later than the second group cows.

Table 10

Indicators of reproductive function of cows after calving $(\mathrm{M} \pm \mathrm{m})$, days

\begin{tabular}{|l|c|c|c|c|c|c|}
\hline \multicolumn{1}{|c|}{ Groups of Animals } & $\begin{array}{c}\text { Litter delay, } \\
\text { goal }\end{array}$ & $\begin{array}{c}\text { III at endometritis, } \\
\text { goal }\end{array}$ & $\begin{array}{c}\text { Duration of allocation } \\
\text { of lohy }\end{array}$ & Yellow Body Lysis & $\begin{array}{c}\text { Time from calving to } \\
\text { first insemination }\end{array}$ & Service-Period \\
\hline \multicolumn{7}{|c|}{ First group calves } \\
\hline I підгрупа, $\mathrm{n}=6$ & - & - & $19,06 \pm 1,20$ & $21,40 \pm 1,20$ & $81,00 \pm 2,0$ & $103,00 \pm 4,0$ \\
\hline II підгрупа, $\mathrm{n}=6$ & - & 1 & $21,20 \pm 2,30$ & $23,80 \pm 1,06$ & $86,00 \pm 1,0$ & $116,00 \pm 2,0$ \\
\hline -III підгрупа, $\mathrm{n}=5$ & 2 & 1 & $24,40 \pm 2,20$ & $26,20 \pm 1,10$ & $92,00 \pm 3,0$ & $120,00 \pm 2,0$ \\
\hline IV підгрупа, $\mathrm{n}=5$ & 2 & 2 & $25,10 \pm 4,05$ & $27,00 \pm 1,00$ & $93,00 \pm 2,0$ & $121,00 \pm 2,0$ \\
\hline \multicolumn{7}{|c|}{ Second group cows } \\
\hline I підгрупа, $\mathrm{n}=8$ & - & - & $18,40 \pm 2,40$ & $20,10 \pm 2,05$ & $78,00 \pm 2,0$ & $98,00 \pm 1,0$ \\
\hline II підгрупа, $\mathrm{n}=8$ & - & - & $18,10 \pm 2,35$ & $20,90 \pm 2,00$ & $79,00 \pm 1,0$ & $100,00 \pm 1,0$ \\
\hline III підгрупа, $\mathrm{n}=3$ & - & 1 & $21,60 \pm 3,10$ & $22,40 \pm 1,20$ & $81,00 \pm 3,0$ & $108,00 \pm 3,0$ \\
\hline IV підгрупа, $\mathrm{n}=3$ & 1 & 1 & $22,80 \pm 2,40$ & $25,60 \pm 1,40$ & $86,00 \pm 2,0$ & $112,00 \pm 2,0$ \\
\hline
\end{tabular}

\section{Conclusions.}

1. In $45.44 \%$ of first-born cows the duration of the third period of genera was more than 9 hours, and in cows of the second - the third lactation only $27.28 \%$ of animals.

2. The body weight of calves received from the secondthird calving cows was $22.6-22.4 \%$ more than the calves received from first calving cows. On average, the body weight of the calves the first subgroups proved by $20.80 \%-21.20 \%$ more than the calves in the fourth subgroups. Below the mass proved and placenta of calves, fourth subgroups (in 1.25 by Times -1.18 by Times, $(P<0.05)$, compared to this indicator of the first subgroups of calves.
3. In cows-2-4 subgroups, the first group, blood viscosity proved probably more than the cows of the first subgroups (in 1.09 , in 1.39 and 1.40 by Times, $(P<0.05)$, and in the research animals of the second group, second, third and fourth subgroups blood viscosity was greater of the first subgroups cows (1.07, 1.30 and 1.40 in by Times, $(P<0.05)$.

4. Increasing length of the rotary process in cows is accompanied by an increase in fibrinogen content in the blood in $2,47-2,04$ by times $(p<0.01)$

5 . The increase in length of the genitive process in cows causes an actangent displacement in the fetus and manifests it- 
self in the indicators of oxygenic homeostasis, maturity of the surfactant lung system, and the decreased viability level of the newborn calves.

6. Duration of the family process negatively plunged to restore the reproductive function of the cows after the calving and service - period in animals of the first subgroups was in 1.17 1.14 by times shorter than in the cows of the fourth subgroups.

\section{References:}

1. Ivashkiv, R.M., Kidla, I.M., Dubinyak L. (2009). Estimation of the status of reproduction of high-performance cows according to the results of obstetric clinical examination. Scientific Bulletin of the Lviv State Academy of Veterinary Medicine. S. Gzhitsky, 11, 2, $84-90$.

2. Yabnskyi, V. A. (2000). Problems of reproduction of animals at the turn of of XXI century. Scientific Herald of the National Agrarian University, 22, $16-21$. rika", 368

3. Kryshtoforova, B.V., Lemeschenko, V.V., Zmyslia, Zh.G. (2007). Biological bases of veterinary neonatology. "Terra Tav-

4. Yabloskyi, V. A., Khomych, S. P., Kalinowski, G. M., Haruta, G.M., Kharenko, M. I., Zavijuha, V. I., Lyubetskoy V. (2006). Veterinary obstetrics, gynecologists and biotechnology of reproduction of animals with the basics of andrology. Tutorial. Vinnitca.: Newbook, 592.

5. Goryainova I.A., Medvedev I.N., S.Y. (2005). Thrombocytic dysfunctions in newborn calves. M., 130.

6. Maximov,V.I., Medvedev, I.N. (2008). Evaluation of platelet functions of calves and piglets in early ontogenesis,11, 50-54.

7. Walker I. (2000). Thrombophiliain pregnancy. J Clin.Pathol / I. Walker,- $580 \mathrm{pp}$.

8. Lisovenko, V. M. (2014).Coagulogram blood cows at the end of the second in the early third period of tvity. Physiology of animals, 6, 35, 27-29.

9. Zamaziy, A. A., Lisovenko, V. M. (2014). Thrombotic hemostasis of cows in the second period of the tiality. Physiology of animals, 1, 34,25-27. DOI: https://doi.org/10.32819/2018.63009

10. Zamaziy, A. A., Kambur, M. D., Lisovenko, V. M. (2014). Physiological properties of blood of the cows of the titic. Physiology of animals, 1,34, 25-27. DOI: https://doi.org/10.31890/vttp.2019.04.17

11. Anastasyeva V.G. (2006). Delayed fetal development - Novosibirsk, 161 pp.

12. Mazurkevych, A. Y., Karpovskyy, V. I., Kambur, M. D., Zamyziy, A. A. (2008). Physiology of animals. Tutorial. Vinnitca: New book, 424.

13. Tsinko, T.F., Romanovsky, V.E. (2007). Blood is an indicator of health. Phoenix, 192

14. Yurchenko L.N., Chereshev, V.A., Gusev, E.Y. (2004). Systemic inflammation and hemostasis system in obstetric pathology. Ekaterinburg: URO RAS, 200

15. Prysyazhniuk, V. P. (2009). State of maternal-fetal circulation and correction of its disorders with the delay in fetal growth: Dis. Candidate Med. Sciences: K.,206

16. Opal S.M, Esmon C.T. (2003). Bench-to-bedsidereview: functional relations hips between coagulation and thein nateimmun eresponse and the irrespective role sinthepathogene sis of sepsis. Crit Care 7(1), 23-38.

17. Hoffman M, Monroe DM. Coagulation (2007): A modern view of hemostasis. Hemato Oncol Clin North Am., 21(1),1-11. https://doi.org/10.1016/j.hoc.2006.11.004

18. Markin, L. B., Palyga, I. E. (2004). Technology of help in chronic prenatal hypoxia. Practical medicine, 3,24 - 27. DOI: $10.1161 /$ circresaha.110.221259

19. Prysyazhniuk V. P. (2009). State of maternal-fetal circulation and correction of its disorders with the delay in fetal growth: Dis. CandidateMed. Sciences: K., 206.

20. Kayumova L.H., (2009). Hemostasis in physiological and complicated gestosis of pregnancy. Med. Almanac, 4, 63-66.

21. Chaikina M. (2008). Pritic miscarriage: developmental factors and features of therapy. Medical aspects of a woman's health, 5 (14), 10-12.

22. Vink, J.Y., Poggi, S.H. (2006). Amniotic fluidin dexand birth weight: istherearelalation shipin diabetics with poorglucemic control. Am. J. Obstet. Gynecol, 195 (3), 848 -850. doi: 10.1016/s0002-9378(00)70343-7.

23. Vereina N.K., Sinitsyn S.P., Chulkov V.S. (2012). Dynamics of hemostasis indicators in physiologically occurring pregnancy. Clinical laboratory diagnostics, 2,43-45.

24. Kambur, M. D., Zamaziy, A. A., Koleschko, A V., Lermontov, A. Yu., Butov, O. V. (2018). Properties of blood cows during the period of their being, their influence on reproductive function of animals and viability of newborn calves. Budapest, Vengryya. Science and Education a New Dimension. Natural and Technical Sciences, VI (17), Issue: 157, 26-29.

25. Glagoleva T.I., Zavalishina, S.Yu. (2017). Aggregative Activity of Basis Regular Blood Elements and Vascular Disaggregating Control oven It in Calves of Milk-vegetable Nutrition. Annual Research s Revier in Biology, 12 (6), 1-7. https://doi.org/10.9734/ARRB/2017/33767

26. Tkacheva, E. S., Zavalishina, S.Yu. (2018). Physiological features of platelet aggregation in newborn piglets. Research Jornal of Pharmaceutical Biological and Chemical Sciences, 9. 5, 36-42 DOI: 10.31588/2413-4201-1883-239-3-61-68

27. Kambur, M. D., Zamazii, A. A., Ostapenko, S. V. (2016). Dynamics of hemostasis indicators in cows in dry period. Biology of animals, 18, 4, 149-154.

Камбур М. Д., Д.вет.н., професор, Сумський національний аграрний університет (Суми, Україна),

Замазій А. А., д.вет.н., професор, Полтавська державна аграрна академія (Полтава, Україна)

Нечипоренко , д.вет.н., доцент, Сумський національний аграрний університет (Суми, Україна)

Калашник О. М., к.вет.н., доцент , Сумський національний аграрний університет (Суми, Україна) 
Матвейчук Д, аспірант, Сумський національний аграрний університет (Суми, Україна)

Калашник М. аспірант, Сумський національний аграрний університет (Суми, Україна)

Вплив реології крові та гемостазу коров на життездатність приплоду та розмноження

Результати проведених досліджень свідчать, що у 45,44 \% корів - первісток тривалість третього періоду родів була більше 9 годин, а у корів другої - третьої лактації лише у 27,28 \% тварин. Морфометрічні показники маси тіла новонароджених телят та плаценти свідчать про умови росту та розвитку плоду, які пов'язані з функціональною активністю фето-плацентарного комплексу і проявляються у телят після народження. У середньому, маса тіла телят перших nідгруп ( тварини отримані від корів з тривалістю третього періоду родів до шести годин) виявилась на 20,80 \% - 21,20 \% більше, ніж у телят четвертих підгруп. Нижче за масою виявилась і плацента телят, четвертих підгруп (в 1,25 рази 1,18 рази, ( $p<0,05)$, у порівнянні з даним показником телят перших підгруп. Підвищення активності фракторів гемостазу та реології крові встановлена у тварин у яких тривалість часу третього періоду родів становила до 12 та більше годин. За цих умов підвищується в'язкість крові тварин в 1,39 - 1,40 рази, ( $p<0,05)$ та в 1,30 - 1,40 раза (р<0,05), вміст фрібриногену в 2,47-2,04 рази (p<0,01). Наведені дані опосередковано свідчать про підвищення в'язкості крові, зниження його кровотоку, особливо по судинам капілярної системи. На нашу думку, це є причиною народження тварин з низькою життєздатністю про що свідчать показники коефіцієнту катаболізму, оксигенового гемостазу, проби Мак Клюр Олдрича, «незріла» сурфрактантна система легень. Відновлення репродуктивної функції корів після отелу і тривалість сервіс - період у тварин перших підгруп була в 1,17 - 1,14 рази коротше, ніж у корів четвертих підгруп.

Ключові слова: гемостаз, реологія, гемостаз, баланс, життєздатність 